\title{
Zielnik miłosny z bluszczem w tle - Maria Pawlikowska-Jasnorzewska i Edgar Allan Poe o sztuce i uczuciach
}

\section{Poetic herbarium with ivy in the background - Maria Pawlikowska- -Jasnorzewska and Edgar Allan Poe about the arts and feelings}

\author{
||l Agnieszka Kulig
}

\begin{abstract}
The purpose of this article is to describe and comment on didactic solutions used at the middle school, related to the poetry of Maria Pawlikowska-Jasnorzewska and the short story of an American writer. The Oval Portrait by Edgar Allan Poe. The described methodological tools were developed as part of the national project conducted by the Institute for Educational Research. The basis for the juxtaposition of various texts are such categories as: the arts, love and nature, all strongly present in the works of the above mentioned artists. Conclusions of methodological nature are accompanied by literary reflection.
\end{abstract}

Key words: poetry, didactics, middle school, the arts, love, motif.

Streszczenie: Celem niniejszego artykułu jest opisanie i skomentowanie rozwiązań dydaktycznych na poziomie gimnazjum, związanych z poezją Marii Pawlikowskiej-Jasnorzewskiej i nowelą amerykańskiego twórcy - mowa tutaj o Portrecie owalnym Edgara Allana Poe. Opisane narzędzia metodyczne powstały w ramach ogólnopolskiego projektu prowadzonego przez Instytut Badań Edukacyjnych. Podstawą do zestawienia ze sobą różnych tekstów są takie kategorie, jak miłość, sztuka i natura, silnie obecne w twórczości wspomnianych artystów. Wnioskom metodycznym towarzyszy refleksja o charakterze literaturoznawczym.

Słowa kluczowe: poezja, dydaktyka, gimnazjum, sztuka, miłość, motyw.

Miłośnikom literatury nie trzeba zapewne przedstawiać dwojga autorów, których nazwiska umieszczono w tytule. I choć dzieli ich wiele - m.in. język, którym się posługiwali, czy ulubione środki wyrazu - w twórczości Marii Pawlikowskiej-Jasnorzewskiej i Edgara Allana Poe da się odnaleźć wspólny mianownik. Płaszczyzną porozumienia zdaje się motyw sztuki i miłości, który jest silnie obecny zarówno u poetki z Krakowa, jak i amerykańskiego nowelisty. Tłem do rozważań na temat literackich podobieństw 
będą lekcje języka polskiego w gimnazjum, na których uczniowie trzecich klas zapoznawali się z wybranymi przykładami twórczości dwojga artystów ${ }^{1}$. Na początek oddajmy głos autorce Pocałunków.

\section{Zielnik poetycki}

Pawlikowska-Jasnorzewska w swoich wierszach często odwoływała się do motywów botanicznych (szczególnie florystycznych), solarnych, akwatycznych itp. Wiemy, że „oprócz miłości, na którą czekała, obchodził ją cały świat, a przede wszystkim przyroda. Zaczytywała się w naukowych książkach przyrodniczych i znała na pamięć mnóstwo łacińskich nazw kwiatów i ziół" (Hurnikowa 1999, 55). O niezwykłej wiedzy na temat tworów natury świadczy choćby fakt, że w swoich utworach „Lilka” twórczo przekształcała ich nazwy za pomocą peryfrazy - „dzięki 46 omówieniom florystycznym obrazuje poetka 29 przedstawicieli świata roślinnego" (Rychter 2011, 271). Jak trafnie stwierdza Sylwia Stolarczyk, autorka pracy Ogród polskiej Safony. O symbolice roślin w poezji Marii Pawlikowskiej-Jasnorzewskiej, artystka, wywodząca się z rodu Kossaków, „potrafiła z precyzją opisać kwiat od łodygi aż po jego duszę" (Stolarczyk 2014, 11). Tym botanicznym tropem podążali również gimnazjaliści, analizując i interpretując wiersze poetki, co znalazło odzwierciedlenie już w samym tytule lekcji (Zielnik miłosny).

Warto już na wstępie wspomnieć o różnych sposobach identyfikowania na lekcji bohaterki tego szkicu. Uczniowie - w ramach przygotowania do zajęć - tworzą bank określeń, za pomocą których mogą opisać Marię Pawlikowską-Jasnorzewską (poetka z Krakowa, autorka „Różowej magii”, poetka miłości, malarka słów i obrazów, czarownica z Krakowa, wnuczka Juliusza Kossaka, studentka ASP w Krakowie, laureatka Złotego Wawrzynu Polskiej Akademii Literatury itp.). Takie działanie z pewnością będzie dla gimnazjalistów ciekawe poznawczo, a także pokaże, w jaki sposób unikać zbędnego powtarzania.

Pierwsze spotkanie uczniów z twórczością Pawlikowskiej-Jasnorzewskiej odbyło za pośrednictwem namalowanego przez nią obrazu $W$ zaczarowanym ogrodzie dwie dziewczyny i $\mathrm{On}^{2}$. Uznałam ten przykład dzieła plastycznego za najbardziej reprezentatywny dla całej działalności artystycznej „Lilki” - to w nim, jak w soczewce, skupiały się wszystkie najważniejsze cechy jej twórczości: pasja do malarstwa wyniesiona z rodzinnego domu,

1 Omawiane w tekście narzędzia dydaktyczne zostały stworzone przeze mnie w ramach badania Dydaktyka języka polskiego $w$ gimnazjum $w$ świetle nowej podstawy programowej wykonanego w ramach projektu systemowego „Badanie jakości i efektywności edukacji oraz instytucjonalizacja zaplecza badawczego”, współfinansowanego przez Unię Europejską ze środków Europejskiego Funduszu Społecznego, realizowanego przez Instytut Badań Edukacyjnych w Warszawie. Każde z narzędzi (dwa scenariusze lekcji oraz pojedyncze zadanie) przetestowano w trzech szkołach i opatrzono komentarzami gimnazjalnych polonistów.

Szerzej o idei narzędzi dydaktycznych patrz: Krzysztof Koc, 2015, Metodyka koncepcyjna - edukacyjna wartość narzędzi polonistycznych (analityczno-interpretacyjnych), „Polonistyka. Innowacje”, nr 1.

2 Obraz dostępny jest pod adresem: http://www.bg.agh.edu.pl/KOSSAK/maria.html, (dostęp: 12.11.2015). Punktem wyjścia do rozmowy o wierszach można uczynić także inny przykład sztuki malarskiej, znajdujący się na tej samej stronie - Kobieta $w$ białej sukni pod magnolia. 
wspomniane zainteresowanie przyrodą i zamiłowanie do poetyckiego opisywania relacji między kobietą a mężczyzną. Utrzymane w ciepłych barwach dzieło (brązy i żółcienie) jednoznacznie wskazywało na inspirację roślinnością: na obrazie ukazano drzewo z bujną koroną, doniczkę, kwiaty i pnącza oraz motyle skrzydła. Można także wysnuć wniosek, że jednym z tematów, które podejmowała, były różne fazy życia człowieka, gdyż płótno zamieszkują osoby młode obojga płci i staruszka. Nietypowy wygląd ostatniej postaci wprowadza do obrazu atmosferę tajemniczości i bajkowości. Rzecz jasna, nauczyciel zamiast tych określeń mógł użyć terminu groteska, jeśli klasa poznała już to pojęcie.

Gimnazjaliści, patrząc na obraz, uruchamiali skojarzenia na temat tego, co interesowało Pawlikowską-Jasnorzewską w otaczającym świecie, co było przedmiotem jej refleksji, w jaki sposób, używając kolorów i prowadząc linie, przedstawiała swoje plastyczne pomysły. Na podstawie uwag przekazanych przez nauczycieli prowadzących zajęcia według scenariusza, można postawić tezę, że rozpoczęcie lekcji od analizy obrazu pozwoliło skupić uwagę uczniów, która podczas interpretacji wiersza jest zwykle mniejsza niż przy omawianiu prozy. Pojawienie się na lekcji dzieła sztuki pozwala również na zwiększenie aktywności chłopców, którzy na ogół nie przepadają za poezją. Gimnazjaliści trafnie wskazywali najważniejsze elementy pracy plastycznej (kobieta; mężczyzna; potwór; starsza kobieta; motyl, bo kolorowe skrzydła; kobiety $w$ sukniach ślubnych).

Kolejnym krokiem na drodze ku lepszemu zrozumieniu przesłania poetki z Krakowa był wspólny namysł nad wierszem Wielki Wóz. Omówienie utworu zostało poprzedzone jego głośnym odczytaniem przez gimnazjalistów. Istotny jest fakt, że interpretacja pozostawała w bliskiej relacji z przywoływanym wyżej obrazem jako kontekstem lekturowym. W celu zainicjowania rozmowy uczniów z wierszem i dziełem malarskim nauczyciel sformułował pytanie problemowe: Co łaczy utwór „Wielki Wóz” z obrazem autorstwa poetki?

$\mathrm{Na}$ tym etapie pracy z tekstem ważne było także wprowadzenie pojęcia miniatury poetyckiej - formy, którą Pawlikowska-Jasnorzewska posługiwała się najczęściej. Działania lekturowe inspirowane były treścią zapisanych na tablicy zadań problemowych: W jaki sposób jest zbudowany wiersz? Wskaż w nim mniejsze czastki; Jak mógłbyś/mogłabyś nazwać taki typ utworu poetyckiego ze względu na jego budowę? Przy współudziale uczniów powstawała definicja tej formy, zawierająca takie cechy, jak niewielka objętość (zazwyczaj cztery wersy) oraz wyraźna puenta, często w postaci metafory. Sugerowana notatka, podkreślająca podwójne znaczenie frazeologizmu prowadzącego do dosłownego lub metaforycznego rozumienia wiersza, przybrała następujący kształt: 
Wędrujemy cygańskim obozem, nocujemy w gwiaździstej grozie, dzisiaj pod Wielkim Wozem, jutro na Wielkim Wozie...

$\longrightarrow$ „(być) raz na wozie, raz pod wozem”

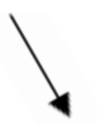

nazwa gwiazdozbioru lub

nazwa jednego z wozów cygańskiego taboru

Dodatkowo warto poświęcić na lekcji nieco czasu na sformułowanie hipotez interpretacyjnych, koncentrujących się na przesłaniu utworu (np. O czym jest ten wiersz? Co go cechuje? Kim sq ci, którzy wędruja? Jakie emocje i przeżycia im towarzysza? Co jest dla nich ważne i dlaczego?).

Poezja Marii Pawlikowskiej-Jasnorzewskiej była niezwykle zmysłowa (Kwiatkowska 2013); poetka pochylała się nad przedmiotami, dostrzegając ich kolor, fakturę, zapach; obserwowała poszczególne fazy ruchu obiektów. Opisywała je z charakterystyczną dla siebie wrażliwością. Można nawet zaryzykować stwierdzenie, że podobieństwo pomiędzy puentą - integralną częścią jej wierszy, a puentylizmem, czyli nurtem w sztuce, którego przedstawiciele posługiwali się drobnymi plamkami barw, jest nieprzypadkowe. Nie chodzi jedynie, abstrahując od pochodzenia wyrazów, o podobieństwo brzmieniowe, ale o fakt, iż „Lilka” tworzyła w podobny sposób co Georges Seurat czy Paul Signiac - zwracając uwagę na momenty, a wśród tematów jej utworów, oprócz roślin i innych stworzeń ze świata ożywionego, pojawiały się niewielkie przedmioty. Tę podwójną perspektywę (zwrot ku naturze i materii nieożywionej) wpisano w kolejne polecenie skierowane do uczniów.

Gimnazjaliści zostali podzieleni na dwie grupy. Pierwszej przypadło w udziale zinterpretowanie miniatur poetyckich związanych przede wszystkim z wodą i powietrzem (Gorzka zatoka, Portret, Areoplan, Zmierzch na morzu, Wybrzeże), zaś kolejnej z przedmiotami codziennego użytku (Miłość, La précieuse, Fotografia, Jesień). W drugim zbiorze wierszy pojawiły się rekwizyty, które można by utożsamiać z kobiecością: szal czerwony i złoty, futro, chiński piesek, parasol oraz róża. Najbardziej problematyczne okazało się odczytanie wymowy wiersza La précieuse (Damulka). Utwór udostępniono gimnazjalistom w poniższej formie:

Widzę Cię w futro wtuloną,

wahającą się nad małą kałużą

z chińskim pieskiem pod pachą, z parasolem i z różą...

I jakżeż ty zrobisz krok w nieskończoność?

(Pawlikowska-Jasnorzewska 1997, 22).

Uczniowie bez sugestii nauczyciela nie byli w stanie wskazać odpowiedzi mieszczącej się w granicach możliwej interpretacji. Pomimo przetłumaczonego tytułu nie potrafili $\mathrm{w}$ bohaterce dostrzec kobiety, która 
koncentruje się na rzeczach błahych (przejście przez kałużę bez zabrudzenia bucików). Mówili o niej jako kobiecie niezależnej i eleganckiej, a jeden z uczniów nazwał ją kobietą samotną. Być może główną przeszkodę stanowił ton wiersza, odwołujący się do nieznanej współczesnemu młodemu czytelnikowi mody i obyczajowości. Rozwiązaniem tak postawionego problemu może być zrealizowanie, przed lekcją właściwą, kilku zadań wprowadzających w atmosferę domu Kossaków i Krakowa z początku XX wieku.

Rozmowa na temat pozostałych miniatur skupiła się wokół stworzenia charakterystyk postaci występujących w wierszu. Za pośrednictwem przeczytanych tekstów uczniowie mogli poznać modną, młodą i zalotną kobietę, potrzebującą jednak poczucia bezpieczeństwa. Spotkali się również z żeńskimi postaciami, które cechowały smutek, choroba, zamyślenie lub złamane serce. Istotnym aspektem doświadczeń lekturowych związanych z wybranymi wierszami wnuczki Juliusza Kossaka są relacje międzyludzkie, a szczególnie związki miłosne. Wśród możliwych zadań, do których warto nakłaniać gimnazjalistów, była próba zrekonstruowania kreacji mężczyzn w przeczytanych miniaturach (Kim sq? Jak sq portretowani? itp.) Przykładowe spostrzeżenia poczynione przez uczniów prezentują się następująco: przedstawiciele płci męskiej są porównywani do marynarza, pasa ratunkowego, morskiej fali, wiatru i powietrza; w utworach autorka Pocałunków podkreśla przede wszystkim dwie cechy mężczyzn: odwagę i siłę.

Ważną częścią działań lekturowych podejmowanych przez gimnazjalistów było też, oprócz ustalenia dominujących środków obrazowania oraz źródeł natchnienia w poezji Pawlikowskiej-Jasnorzewskiej (przyrody - morza, roślin - i miłości), określenie funkcji, jaką w utworach autorki Różowej magii pełni natura. Rezultatem tych poszukiwań było sformułowanie kilku wniosków. Natura w miniaturach poetyckich występuje w roli tła do ukazywania rodzącego się lub - wręcz przeciwnie - gasnącego uczucia, punktu wyjścia do rozmów na ten temat. Poszczególne elementy świata roślin i zwierząt uczniowie odczytywali jako odpowiedniki konkretnych cech poetyckich par.

$\mathrm{Na}$ zakończenie opisywanej lekcji zaproponowano dwa ćwiczenia mające na celu przeniesienie zdobytej wiedzy o wyznacznikach poezji autorki Niebieskich migdałów w obszar codziennego doświadczenia gimnazjalistów. Chętne osoby zostały poproszone o wybór jednego z poznanych na lekcji wierszy i zadedykowania go bliskiej osobie oraz podanie powodu sięgnięcia po ten konkretny tekst. Zadanie domowe natomiast polegało na wykonaniu polecenia: Jakie sytuacje życiowe uzasadniać moga odwoływanie się do wierszy Marii Pawlikowskiej-Jasnorzewskiej? Stwórz kilkuzdaniowa wypowiedź, uwzględniając różne sytuacje komunikacyjne. 


\section{Kossakówka - historia niezwykłej rodziny}

Lepszemu zrozumieniu twórczości malarskiej PawlikowskiejJasnorzewskiej i jej poczynań na niwie poetyckiej służyć może wprowadzenie na lekcję kontekstu biograficznego. Wnioski płynące z realizacji w klasach trzecich - kilku poleceń, odwołujących się w bezpośredni sposób do faktów z życia artystki, są optymistyczne. Narzędzie dydaktyczne zatytułowane Kossakówka - historia niezwykłej rodziny wykorzystane zostało na lekcji lub w formie zadania domowego. Funkcjonowało ono jako dobry wstęp do interpretowania wierszy „czarownicy z Krakowa”. Walory tego zestawu zadań zostały mocno wyeksponowane w klasach, w których użycie kontekstów plastycznych podczas pracy z literaturą przynosiło w przeszłości dobre efekty, oraz wśród tych uczniów, którzy przejawiali szczególne zainteresowanie malarstwem, $\mathrm{np}$. w zespołach o profilu artystycznym.

Narzędzie skupiało się na wykonywaniu działań po lekturze krótkich opisów mieszkańców rodzinnego domu poetki: Jerzego, Wojciecha, Magdaleny, samej Marii i Juliusza oraz jednego „nieprzypisanego" do żadnej z osób cytatu, mówiącego o interesującym zwyczaju nadawania pseudonimów. Dla przykładu: Juliusz Kossak został scharakteryzowany jako

ten, który zapoczątkował linię artystyczną rodu Kossaków. Był malarzem-poetą, który z koni robił poematy. Dziadek był to zażywny pan z siwymi długimi wąsami i pięknym orlim nosem. Nosił małą, aksamitną bośniacką czapeczkę haftowaną złotem i stale kopcił fajeczkę. Kochał dzieci. Lilce i Madzi zrobił kiedyś akwarelą portrety ich lalek na drewnianych konikach z biegunami. W jego pracowni stały wielkie, oszklone szafy, pełne autentycznych starych mundurów i starej broni. W głębi stał wielki turecki namiot. Na ścianach i kamiennej posadzce wzorzyły się piękne tureckie i perskie dywany, przeważnie od przyjaciela Dziadzi z Maroka. Juliusz siedział przy dużym weneckim oknie na czarnym ceratowym fotelu i malował konie przed sztalugą rzeźbioną w łabędzie głowy (Samozwaniec 1956).

Magdalena Samozwaniec opisywała swoje relacje z siostrą w taki sposób:

Moje życie do czasu wojny światowej było jednym nieprzerwanym ciągiem samych radości. Koło mnie nierozerwalnie, mimo swoich trzech mężów, szła wciąż największa miłość mojego życia - „czarownica z Krakowa”, jak ją nazywał Tuwim - moja siostra Maria. Przez nasze salony przewijały się pokolenia mistrzów pióra (A. Asnyk, H. Sienkiewicz, S.I. Witkiewicz), pędzla (J. Malczewski), muzyki (I.J. Paderewski) i wielu innych znamienitych artystów. W starym krakowskim dworku zimą i latem błyszczało i grzało nas słońce, nasz przecudny ojciec Wojciech Kossak, koło niego krzątała się nasza matka Maniusia z Kisielnickich, srogi złotowłosy anioł z rózgą, ale zarazem i z niebywałym poczuciem humoru. Cała atmosfera naszego domu była tak przesiąknięta wybuchami śmiechu, że nic dziwnego, iż jedna z córek musiała wyrosnąć na satyryczkę (Samozwaniec 1956). 
Natomiast osobliwa tradycja mieszkańców krakowskiego domu została sportretowana w następującym fragmencie:

Ciekawym zwyczajem, który stopniowo rozrósł się pod dachem Kossakówki, było nadawanie dodatkowych imion członkom rodziny. Wojciech Kossak był więc dumnym „Tatkiem” albo „Woniem”, Marię Kossakową ochrzczono „Manią, Maniusią” i „Mamidłem”. Maria Kossak często występowała jako „Szczurek”, „Lilczur”, „Lilka”. Juliusz Kossak był panującym „Preziem” (od prezesa), a jego żona, Zofia Kossakowa „Ciapuchną”. Magdalena była „Magasiem” (Hurnikowa 1999).

Dzięki zapoznaniu się z informacjami o członkach rodziny Pawlikowskiej-Jasnorzewskiej uczniowie mogli uzupełnić schemat drzewa genealogicznego, wpisując $\mathrm{w}$ wyznaczonych miejscach imiona postaci wraz $\mathrm{z}$ odpowiednimi przydomkami. W tekstach ukryto również przesłanki dotyczące fizjonomii bohaterów, co ułatwiło ich późniejszą identyfikację na załączonych fotografiach. Zdjęcia przedstawiały Kossaków uchwyconych w charakterystycznych pozach lub z konkretnymi rekwizytami odpowiadającymi ich profesji. Przy okazji realizacji tego zadania warto zadbać o to, aby gimnazjaliści dostrzegli i nazwali uczucia siostrzane, rodzicielskie oraz pozostałe emocje, jakie gościły w rodzinnym domu poetki i zostały uwiecznione w przywoływanych fragmentach.

Ostatnim ogniwem łańcucha poleceń było zaznaczenie na wydrukowanej mapce Krakowa położenia Kossakówki i podanie nazwy ulicy, przy której mieścił się słynny dom (ul. Zwierzyniecka/Plac Kossaka 4).

Przetestowanie tego narzędzia dydaktycznego w szkołach pozwoliło na uzupełnienie polecenia o ważny dopisek. Aby zminimalizować ryzyko plagiatu, uczniowie zostali poproszeni o wpisanie w wyznaczonym miejscu adresu strony internetowej, na której sprawdzali umiejscowienie Kossakówki. Jedna z polonistek zauważyła bowiem, iż „wszystkie osoby zaznaczyły na mapie ulicę. Kiedy jednak zapytałam, skąd zaczerpnęli tę informację, kilka osób przyznało, że wykorzystało wyszukiwarkę Google”3.

Jestem przekonana, że omawianie twórczości Pawlikowskiej-Jasnorzewskiej w gimnazjum według zaprezentowanego klucza pozwoli na wykształcenie u uczniów postawy poszukiwaczy artystycznych inspiracji i biograficznych śladów, badaczy koligacji rodzinnych, a także interpretatorów nieliterackich dzieł kultury. Obcowanie z obrazami - funkcjonującymi jako konteksty lekturowe - wpłynąć może na zmniejszenie dystansu między młodym odbiorcą a wierszem, niwelując poczucie obcości oraz dając szansę poznania dawnego świata zatrzymanego na płótnach, czarno-białych fotografiach i w miniaturach poetyckich.

Wprowadzenie dodatkowych nawiązań miało na celu ukazanie, iż poezji „Lilki” nie można rozpatrywać jako aktywności „wyizolowanej”, ale korespondującej z innymi dziedzinami sztuki i posługującej się tymi samymi

${ }^{3}$ Była to wypowiedź nauczycielki, która uczyła w jednej ze szkół biorących udział w badaniu IBE. 
motywami. Przedstawione pomysły metodyczne były ostatecznym potwierdzeniem poczesnego miejsca, jakie sztuka zajmowała w zawodowym i prywatnym życiu Marii Pawlikowskiej-Jasnorzewskiej. Przede wszystkim jednak miały stanowić próbę stworzenia takiej sytuacji dydaktycznej, która zaowocowałaby odnalezieniem się współczesnego gimnazjalisty w przestrzeni poezji „polskiej Safony” i związanych z nią kontekstów oraz wartości.

\section{Niesamowita historia pewnego obrazu - Portret owalny E.A. Poe}

Tytuł niniejszego artykułu brzmi: „Zielnik miłosny z bluszczem w tle". O ile koncepcja kryjąca się za pierwszą częścią zdania powinna być już dla czytelników jasna, o tyle jego druga część - odnosząca się do noweli Edgara Allana Poe - wymaga wyjaśnienia. Chciałabym bowiem, aby Portret owalny ${ }^{4}$ był traktowany w kategoriach kontekstu do rozważań na temat twórczości Pawlikowskiej-Jasnorzewskiej, jak i samodzielnego utworu wartego zainteresowania i omówienia na lekcji języka polskiego.

$\mathrm{Na}$ początku trzeba poczynić pewne zastrzeżenie. Ze względu na to, że krótki tekst Poego, osoba samego pisarza oraz specyfika czasów, w których żył i tworzył, mogą być nieznane uczniom, zasadnym wydawało się, aby to działania nauczyciela wysunęły się podczas lekcji na pierwszy plan, a on sam mógł odegrać rolę przewodnika po noweli. Wbrew pozorom nie stało to $\mathrm{w}$ sprzeczności $\mathrm{z}$ traktowaniem ucznia jako aktywnej strony procesu dydaktycznego. Gimnazjaliści mogli brać udział w lekcji na wiele sposobów - tworząc przekład intersemiotyczny, pracując z tekstem, działając metodą dramy. Pozór biernej postawy ucznia mógł być także efektem kilku poleceń, które odwoływały się do samego tekstu i innych prac Poego. Uznałam jednak, że zadania te są cenne. Uczą dobrego czytelniczego nawyku - kilkukrotnej lektury tego samego utworu, odkrywania w nim nowych sensów - i powinny znaleźć się w scenariuszu.

Podobnie jak miało to miejsce w trakcie lekcji Zielnik miłosny, punktem wyjścia do rozmów o literackich dokonaniach amerykańskiego twórcy był obraz. Wybór dzieła plastycznego w kontekście omawiania Portretu owalnego był jednak - jak stwierdzili poloniści podsumowujący pracę $\mathrm{z}$ narzędziem dydaktycznym $\mathrm{w}$ ramach projektu - intrygujący, ponieważ oczom uczniów ukazał się... utrzymany w surrealistycznej konwencji portret Poego. Tym samym rozmowa o tytułowym obrazie rozpoczęła się od wymiany uwag na temat podobizny autora Kruka. Na marginesie należy dodać, że umieszczony $\mathrm{w}$ prawym dolnym rogu płótna ptak był dla dorosłych odbiorców czytelnym znakiem rozpoznawczym nowelisty. Dla uczniów kruk stanowił symbol zła i zawierał sugestię dotyczącą czasu akcji utworu.

4 Z całością tego niewielkiego utworu można zapoznać się pod adresem: wolnelektury.pl/katalog/lektura/ portret-owalny.html, (dostęp: 10.11.2015). 
Malarski wizerunek stał się więc przyczynkiem do interpretowania konkretnego utworu. Cechy twórczości Poego takie jak: tajemnicza i groźna atmosfera, częsty wybór nawiedzonych budowli jako tła wydarzeń, obecność zbrodni, śmierci i szaleństwa, miały zostać ujawnione podczas omawiania uzupełnionego przez uczniów obrazu.

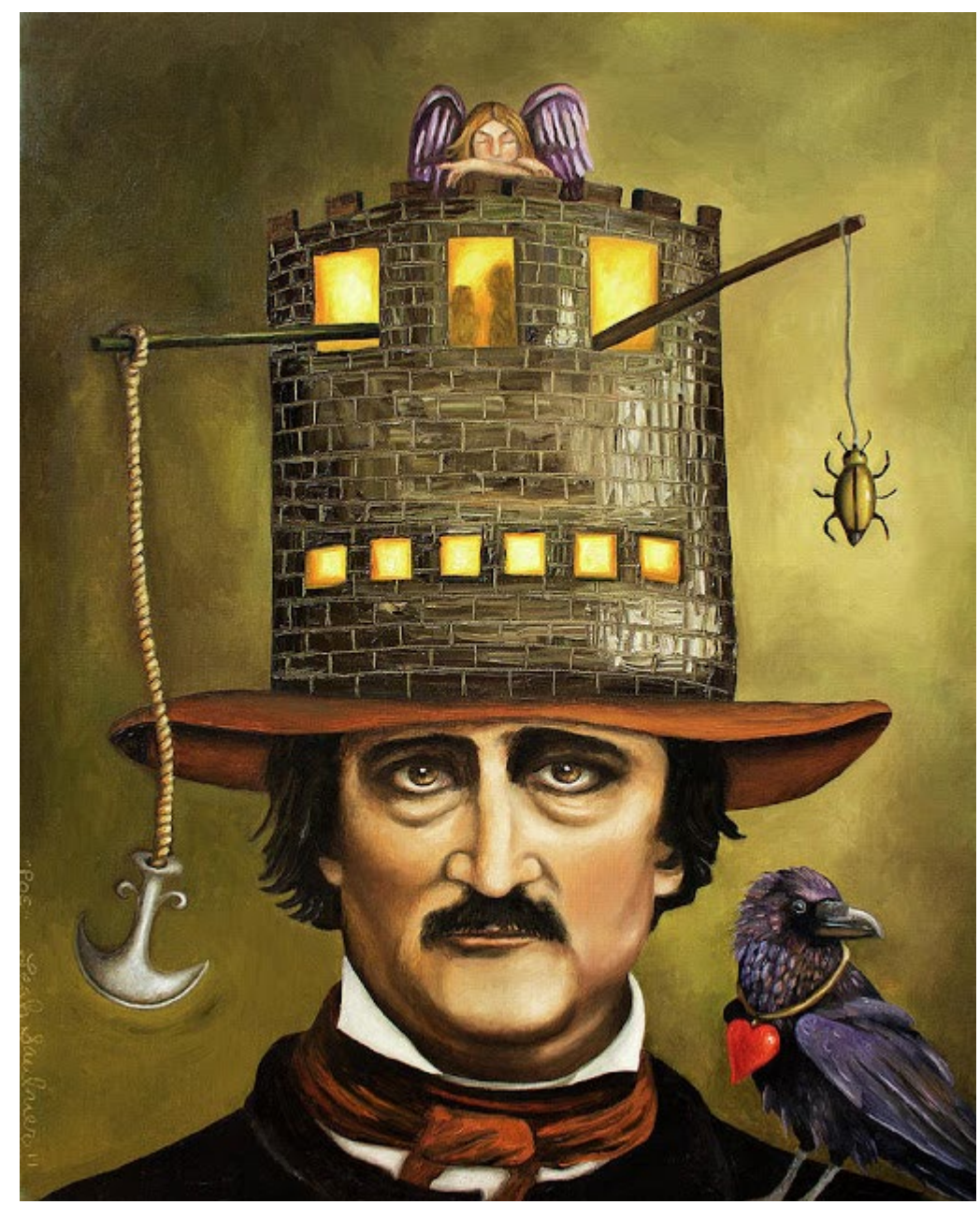

Źródło: L. Saulnier, Edgar Allan Poe,

fineartamerica.com/featured/edgar-allan-poe-leah-saulnier-the-painting-maniac.html.

Gimnazjaliści wypełniali przestrzeń wokół postaci, wpisując symboliczne znaczenie przedstawionych przedmiotów, mogli także zgłaszać własne propozycje. Zdaniem uczniów kotwica symbolizowała poszukiwanie bezpiecznego portu (schronienia) przez rannego narratora. Rondo kapelusza, będące równocześnie podstawą zamkowej wieży, gimnazjaliści mogli odczytać jako metaforę procesu twórczego (opowieści rodzą się w umyśle). Okna w wieży to z kolei element budzący grozę (ich układ przypomina bezzębną twarz) - element charakterystyczny dla utworów Edgara Allana Poe. Cienie na wieży - wyższy i niższy - były utożsamiane z postaciami malarza i jego żony, natomiast naszyjnik z sercem symbolizował historię tej pary, którą połączyło uczucie. Anioła i robaka można postrzegać w kategoriach końca ziemskiego życia, rozkładu tego, co materialne. 
Trzeba w tym miejscu zaznaczyć, że uczniowie, nie znając większej liczby nowel pisarza, odwoływali się do luźnych skojarzeń związanych $\mathrm{z}$ tematyką prezentowanego obrazu. Dlatego też tam, gdzie namalowano wahadło (wyraźna aluzja do utworu Studnia i wahadło), widzieli kotwicę, a widniejący na obrazie robak nie został przez nich powiązany z opowiadaniem Złoty żuk - inną znaną pracą artysty. Poloniści, którzy zamierzają omawiać utwór Poego w kontekście jego portretu, powinni zapoznać się wcześniej choćby z najpopularniejszymi nowelami twórcy, aby móc wskazać gimnazjalistom odniesienia do innych tekstów autora Czarnego kota.

"Czytanie symboliczne" reprodukcji na początku lekcji pełniło funkcję aktywizującą. Uczniowie byli w stanie wyjaśnić przekaz dzieła malarskiego na podstawie wcześniejszej, samodzielnej lektury tekstu (Portretu owalnego). Nauczyciele zwracali uwagę na fakt, że choć zadanie odznacza się wysokim poziomem trudności, interesowało nawet nieco mniej zdolnych uczniów. Ci chętnie dorysowywali pozostałe symbole mające związek z nowelą: pędzel (najważniejszy rekwizyt), owalny kształt (tytułowy portret), świece (towarzyszące odkryciu obrazu), księżyc i gwiazdy (czas akcji), zarys zamku (miejsce akcji) czy plamy czerwonego koloru (krew, zbrodnia).

Ścieżka interpretacyjna wiodła uczniów aż do zauważenia przez nich szkatułkowej kompozycji noweli. W tekście wyróżnić można bowiem dwie opowieści: o rannym wędrowcu szukającym schronienia w zamkowej wieży oraz historię miłosną artysty i kobiety niezwykłej urody, poprzednich mieszkańców posiadłości. Ponadto „w opowiadaniu pojawia się narracja w narracji, mamy więc do czynienia z obrazem w obrazie tworzącym trzeci obraz - miniaturę Poego" (Gortat 2015).

Ważnym elementem lekcji było odczytanie przesłania utworu. Nauczyciel, rysując na tablicy dwa kręgi podpisane „sztuka” i „życie”, zwracał się do uczniów z poleceniem: Opowieść o malarzu i jego pięknej żonie $z$ „Portretu owalnego” porusza temat sztuki i życia. Za pomoca strzałki zaznacz kierunek, $w$ jakim odbywa się ruch, określajacy relację między tymi wartościami $w$ podanej historii. Gimnazjaliści w przeważającej mierze poprawnie wykonywali to zadanie, malując graf wiodący od „życia” do „sztuki” i wyszukując najbardziej reprezentatywny fragment utworu, obrazujący ten związek. Były to słowa wypowiedziane przez malarza: Zaiste! To „życie” samo!. Mianem życia samego została nazwana sztuka, która może być siłą niszczącą. Jej uosobieniem stał się artysta, który stopniowo pozbawiając życia swoją ukochaną, odbierając jej siły witalne, wpisał się w model zachowań „mężczyzny-bluszcza”.

Lepszemu zrozumieniu Portretu owalnego i poznaniu szczegółów warsztatu jego twórcy służyło także zaprezentowanie uczniom fragmentu rozprawy Poego, dotyczącego technik budowania tekstów według określonych prawideł. Cytat udostępniono na lekcji w następującej formie: 
I teraz, pamiętając, że chcę osiągnąć cel najwyższy, doskonałość pod każdym względem, zadałem sobie pytanie: „Który spośród tematów melancholijnych jest powszechnie odczuwany przez ludzi jako najbardziej melancholijny?”, „Śmierć”odpowiedziałem bez wahania. „A kiedy - pytałem dalej - ten najbardziej melancholijny temat jest najbardziej poetyczny?” (...) Wtedy, kiedy jest najsilniej związany z Pięknem; to znaczy, że śmierć pięknej kobiety jest niewątpliwie najbardziej poetycznym tematem świata i tak samo nie ulega wątpliwości, że temat ten brzmi najlepiej w ustach człowieka, który stracił ukochaną istotę". (...) Zawsze sądziłem, że ścisłe ograniczenie przestrzeni jest absolutnie konieczne przy wydarzeniu odciętym od świata, gdyż działa jak rama w obrazie. (...) Postanowiłem więc umieścić kochanka w jego pokoju - w pokoju uświęconym dla niego pamięcią o tej, która tam bywała. Pokój ukazałem jako bogato urządzony ${ }^{5}$ (Poe 1972, 38-40).

Za najbardziej poetycki i melancholijny temat twórczy można uznać rzeczywiście śmierć wspaniałej kobiety - panny młodej. W utworze mieliśmy także do czynienia ze ścisłym ograniczeniem przestrzeni. Mowa tutaj oczywiście o zamku, skrytym w ciemnościach, położonym daleko od innych siedzib ludzkich. Nie do podważenia w kontekście noweli był także argument o niezwykłej dbałości o szczegółowe i malarskie opisywanie miejsca akcji, czyli pokoju na wieży, gdzie znajdował się tajemniczy obraz.

Lekcję zamykała propozycja działań dramowych. Było to przedstawienie improwizowane, w trakcie którego klasa, poznawszy już treść i przesłanie utworu, niejako „wchodziła w ramy obrazu” namalowanego przez Edgara Allana Poe. Scena ta była zarówno zobrazowaniem przeczytanego już tekstu, jak i jego kontynuacją, a samo ćwiczenie miało na celu pełniejsze zrozumienie motywacji bohaterów. Zadaniem uczniów - po uprzednim podziale na grupy - było wcielenie się w cztery główne postaci i wygłoszenie spontanicznych kwestii w imieniu: owładniętego szaleństwem artysty, gasnącej w oczach panny młodej, jej ożywającej podobizny i postaci narratora, komentującego historię powstania portretu.

Rekwizytem, który „ożywiał” i udzielał „głosu” poszczególnym bohaterom, stał się - realny lub jedynie wyobrażony - pędzel, którym operował malarz. Zasugerowanie uczniom odpowiedniej aranżacji przestrzeni podczas odgrywanej sceny (za pomocą zapisu na tablicy, odpowiedniego ustawienia krzeseł) pozwoliło na głębsze, bardziej widoczne odgrodzenie świata rzeczywistego od obszaru sztuki.

\section{Zielnik miłosny z bluszczem w tle - podsumowanie}

Co zatem łączy życie i twórczość Marii Pawlikowskiej-Jasnorzewskiej z omówionym na lekcji utworem Edgara Allana Poe? Wydaje się, że można wyróżnić kilka punktów wspólnych, pamiętając o tym, że zaprezentowane działania metodyczne wieść miały do formułowania uczniowskich spostrzeżeń i zachęcać do lekturowych odkryć.

\footnotetext{
5 Pogrubieniem zaznaczono najważniejsze reguły tworzenia tekstów według autora, które znalazły odzwierciedlenie w opowieści o owalnym portrecie. Wszystkie wyróżnienia są mojego autorstwa - AK.
} 
Już na wstępie dostrzec można, że poetka i nowelista upodobali sobie krótkie, skondensowane formy wyrazu, będące doskonałą podstawą do snucia rozważań na temat relacji międzyludzkich. Podobnie jak miejsce akcji utworu Poego obejmowało właściwie jedno pomieszczenie - zamkową komnatę, tak i poetka posługiwała się ograniczonymi środkami wyrazu, by na przestrzeni kilku wersów dzielić się refleksjami o świecie i opisywać własne wnętrze.

Również nie bez powodu w niniejszym artykule pojawiło się tak wielu mistrzów pędzla: Kossakowie, Pawlikowska-Jasnorzewska czy ogarnięty szaleństwem malarz z Portretu owalne go. Sztuka była jednym z najważniejszych tematów literackich podejmowanych przez oboje artystów. Można pokusić się nawet o stworzenie opozycji pomiędzy wierszami "czarownicy z Krakowa”, które skupiały się głównie na docenianiu znaczenia drobnych przedmiotów, tak licznie występujących w rodzinnej Kossakówce i którym tak chętnie oddawała głos w swojej poezji („sztuka użytkowa”), a sztuką przedstawianą przez Poego jako siła niszcząca, odbierająca życie, a przez to niemal abstrakcyjna. Paradoksalnie, mimo wyraźnego nacechowania twórczości PawlikowskiejJasnorzewskiej tradycyjnie pojmowaną kobiecością, o czym świadczy choćby zamiłowanie do natury, objawiające się tworzeniem przez autorkę poetyckiego zielnika pieczołowicie wyklejanego kolejnymi wierszami, to bohater noweli Poe okazuje się „mężczyzną-bluszczem”, dając tym samym przykład negatywnie pojmowanej „botaniczności”.

\section{Bibliografia:}

Gortat Agnieszka, 2015, W pół drogi między studium charakteru a tajemnicami innego świata - funkcja fantastycznego motywu obrazu na wybranych przykładach (M.G. Lewis, E.A. Poe, L. Sztyrmer), „Podteksty”, nr 1.

Hurnikowa Elżbieta, 1999, Maria Pawlikowska-Jasnorzewska. Zarys monograficzny, Katowice.

Kwiatkowska Agnieszka, 2013, „Pomnożona przez pięć zmysłów”. Sensualność w poezji Marii Pawlikowskiej-Jasnorzewskiej, „Polonistyka”, nr 5.

Pawlikowska-Jasnorzewska Maria, 1997, Pocałunki, Białystok.

Poe Edgar Allan, 1972, Filozofia kompozycji, Żurowski M. (przeł.), „Przegląd Humanistyczny", nr 5.

Rychter Joanna, 2011, Peryfrazy nazw florystycznych w poezji Marii Pawlikowskiej-Jasnorzewskiej, „Studia językoznawcze. Synchroniczne i diachroniczne aspekty badań polszczyzny", Tom 10.

Samozwaniec Magdalena, 1956, Maria i Magdalena, Kraków.

Stolarczyk Sylwia, 2014, Ogród polskiej Safony. O symbolice roślin w poezji Marii Pawlikowskiej-Jasnorzewskiej, dokument elektroniczny. 


\section{O Autorce:}

Agnieszka Kulig - doktorantka w Katedrze Polonistycznej Edukacji Nauczycielskiej na Wydziale Polonistyki Uniwersytetu Jagiellońskiego. Twórczyni innowacyjnych narzędzi metodycznych w ogólnopolskim projekcie badawczym „Dydaktyka literatury i języka polskiego w gimnazjum w świetle nowej podstawy programowej" (2012-2014, IBE), a także koordynatorka studenckich działań w krajowym programie „Akademickie Centrum Kreatywności" (2014-2015, MNiSW). Zainteresowania naukowe doktorantki koncentrują się wokół wykorzystywania potencjału dydaktycznego mediów społecznościowych oraz najnowszej literatury dla młodzieży. 
Polonistyka. Innowacje 